\title{
Environmental sustainability of the clementine production systems in Italy and Spain: an approach based on Life Cycle Assessment
}

\author{
B. F. Nicoló ${ }^{1}$, M. C. De Salvo ${ }^{1}$, C. Ramírez-Sanz ${ }^{2}$, A. V. Estruch ${ }^{3}$, \\ N. Sanjuán ${ }^{2}$, G. Falcone ${ }^{1} \&$ A. Strano ${ }^{1}$ \\ ${ }^{1}$ Department of Agriculture, \\ University Mediterranea of Reggio Calabria, Italy \\ ${ }^{2}$ Department of Food Technology, \\ University Polytechnic of Valencia, Spain \\ ${ }^{3}$ Department of Economics and Social Sciences, \\ University Polytechnic of Valencia, Spain
}

\begin{abstract}
The first step towards a sustainable agriculture is to know the impacts that it generates. Although this is a complex task, since the environmental impact of agriculture depends not only on the production system (e.g. conventional or organic) and farmer practices, but also on the production site (soil and climate conditions). The aim of this study is to assess the environmental impact of clementine production farming systems (conventional, CFS, and organic, OFS) in Italy (Calabria region) and Spain (Comunidad Valenciana) through Life Cycle Assessment (LCA). The functional unit to which the results were referred was 1 hectare $\left(\mathrm{ha}^{-1}\right)$. The system boundaries considered were from "farm gate to farm gate", which included the production of the machinery, fertilizers and pesticides and also the field operations. The study is based on one year of primary data, collected from surveys of 19 Italian and 23 Spanish farmers. Ten impact categories were assessed by CML2001 and USEtox methods. No significant differences were found between CFS and OFS in both countries and the impacts present a high variability depending on the farm. In CFS the fertilizers production is the stage most impacting in almost all categories (Global Warming Potential: Italy $92 \%$ Spain 89\%; Acidification: Italy 91\% - Spain 80\%) with the exception for the Ecotoxicity in which field operations have a great contribution (Spain: 97\%; Italy:
\end{abstract}


$78 \%$ ). Regarding OFS, no stage contributes specifically to all the impacts. The main difference between Italian and Spanish organic farms arises in the Ecotoxicity category. In Italy the stage with the greatest contribution is the production of fertilizers (87\%), whereas in Spain it is the field operation (95\%). In general, the impacts generated by OFS are lower than for CFS. The LCA results of this study allow identifying those agricultural practices that can help to reach a more environmentally sustainable agriculture.

Keywords: life cycle assessment (LCA), citrus crops, comparative assessment, environmental performance.

\section{Introduction}

Agro-ecosystems are big producers of significant impacts on the principal environmental compartments (air, water and soil) producing greenhouse gasses and other emissions. Nowadays, farms should be planed and managed in accordance with criteria that lead to eco-friendly practices to reduce the environmental pressure. Therefore, a sustainable agriculture is now clearly an objective recognized and indispensable to achieve the sustainability criteria by the application of methods and techniques, which identify the environmental hotspots of the agricultural processes and to improve their environmental performance.

The worldwide production of citrus fruit, in 2012, was 131.28 million of tons, with a planted area of 8.79 million of $\mathrm{ha}^{-1}$. In Europe, the main citrus fruit producing countries are Spain and Italy, with 318,700.0 ha ${ }^{-1}$ and 146,294.0 $\mathrm{ha}^{-1}$ of citrus fruit respectively [1]. The largest citrus area in Spain is Comunidad Valenciana, with $178,361 \mathrm{ha}^{-1}$ in 2010 of which $37 \%$ was Clementine with a production of 1.181 millions of tons [2]. In Italy, after Sicily, the second region with the largest citrus surface is Calabria with $35,185 \mathrm{ha}^{-1}$, of which the $35.61 \%$ were Clementine [3] with a production of 4.952 millions of tons [4]. Taking into account the great surface of citrus in these regions and the impacts generated by agriculture, reducing the environmental impact of this crop presents a goal to be achieved.

But farmers need information about the causes of environmental impacts in order to promote environmentally sound agricultural production. Life Cycle Assessment (LCA) methodology has proved to be a valuable tool for the environmental evaluation of farming systems. LCA is a compilation and evaluation of the inputs and outputs and of the environmental impacts of a product system [5]. Some agricultural LCA studies have assessed specific agricultural production systems, including oranges [6-8]; others have compared systems such as conventional versus organic farming $[9,10]$. Although those studies have addressed the differences between the farming systems regarding environmental impacts, the results from LCA studies are affected by different sorts of variations. In fact, some studies $[11,12]$ have highlighted the variations between the farms or scenarios within the same type of production system, even within the same region. A way to tackle this variability is to define representative systems and to quantify the uncertainty linked to the variability by using Monte-Carlo analysis [13]. Another option is to study each farm separately, since it can help us to differentiate 
results among farms and also to define the potential for improvement of environmental impact management in individual farming enterprises. As Mouron et al. [11] state, the promotion of environmentally sound farming is not only a question of choosing a farming system (e.g. organic vs. integrated farming) but an understanding of the system specific management influence is crucial.

In this study, a comparative analysis of two cropping systems, organic and conventional, in two different production site, Comunidad Valenciana and Calabria Region, has been conducted by the LCA methodology in order to highlight the differences and to identify those agricultural practices that can help to reach a more environmentally sustainable agriculture.

\section{Materials and methods}

\subsection{Life Cycle Assessment}

The LCA methodology, according to ISO guidelines $[14,15]$ has been used in this comparative analysis in order to quantify the environmental impacts produced in the cultivation stage of clementine. LCA is an environmental sustainability tool that comprises four main phases defined by the ISO standards: goal and scope definition, inventory analysis, impact assessment and interpretation.

\subsubsection{Goal and scope definition}

The main objective of the study was to compare organic and conventional clementine production systems in the Comunidad Valenciana and Calabrian Region.

The functional unit (FU) is the reference unit to which the system's input and output are related [16]. In this study, the FU chosen is 1 ha of clementine at the farm gate.

The study is based on one year of primary data corresponding to the season 2009-2010. Input and output data have been collected directly by questionnaires and interviews with farmers. The study has examined 43 clementine farms, 23 Spanish and 19 Italian. From the 23 Spanish farms are located in Comunidad Valenciana, 12 correspond to organic production $\left(\mathrm{OFS}_{\mathrm{Sp}}\right)$ and 11 are conventional $\left(\mathrm{CFS}_{\mathrm{Sp}}\right)$ have been considered. The Italian farms are in the Calabria Region, 9 carry out organic farming $\left(\mathrm{OFS}_{\mathrm{It}}\right)$ and 11 are conventional $\left(\mathrm{CFS}_{\mathrm{It}}\right)$.

According to Bentrup [17], LCA studies do not always cover all life cycle stages of a product, but can be restricted to defined parts of it, for example in socalled "cradle to gate" or "gate to gate" studies. In this study, the system boundary considered was from "farm gate to farm gate", which included the use of the machinery, the production of fertilizers, pesticides and fuels, the field operations, as depicted in fig. 1. Irrigation and transport of fertilizers and pesticides were excluded due to lack of data. The machinery manufacturing was excluded because machinery is mostly rented. Thus the use of the machinery is higher that if it was used only by one farmer. Furthermore, a study carried out by Frischknecht et al. [18] shows that the production of capital goods for agriculture contributes to cumulative energy demand whereas the contribution to other impact categories is not significant. 


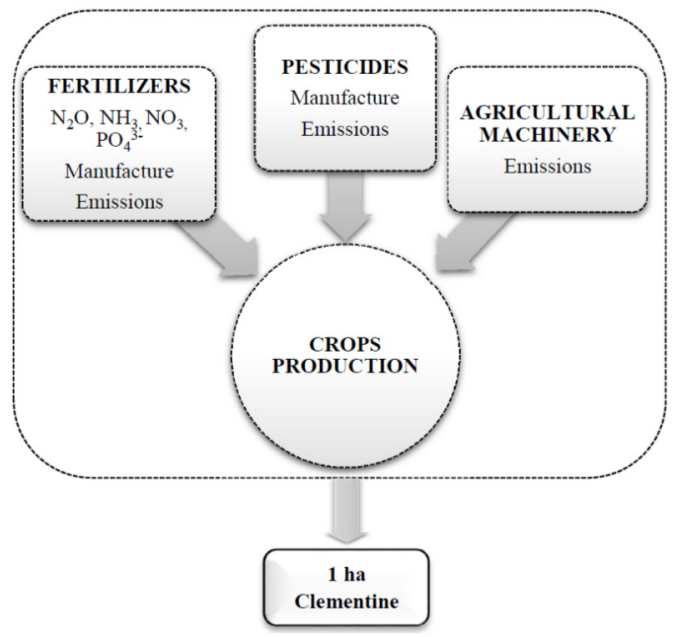

Figure 1: System boundaries of the clementine crop.

\subsubsection{Life Cycle Inventory (LCI)}

Life cycle inventory (LCI) analysis involves the collection of data defined by the materials and energy used in the system, emission to air, liquid effluents and solid wastes discharged into the environment [19].

Data regarding the resource consumption and emissions produced during the fertilizers and pesticides manufacture were taken from the Ecoinvent 2.1 database, [20]. The procedure suggested from Audsley et al. [21], was used to calculate the data of those active ingredients not included in Ecoinvent database. Regarding the mineral oil, used as insecticide, the manufacturing process of the kerosene in Ecoinvent 2.1 has been considered due to its similar properties.

For the manufacture process of those inorganic fertilizers not included in Ecoinvent 2.1, and the organo-mineral complex considered as inorganic, the data suggested from Patyk and Reinhardt [22], have been used.

Data on tractor emissions have been calculated from Ecoinvent database, while emissions from weeding machine manual has been obtained according to Oficina Catalana de Canvi Climàtic [23].

The application of fertilizers generates emissions that have been calculated. To estimate $\mathrm{N}_{2} \mathrm{O}$ emissions the IPCC Guidelines [24] were followed. To estimate $\mathrm{NH}_{3}$ emissions, the amounts of both ammoniacal nitrogen and organic fertilizers were obtained from the register of fertilizers suggested from MAGRAMA [25] and Organozoto fertilizzanti SPA [26]; then $\mathrm{NH}_{3}$ emissions were calculated from the method suggested by Bentrup et al. [27]. $\mathrm{NO}_{3}$ and $\mathrm{PO}_{4}{ }^{3-}$ leaching was calculated according to MARM [28], and Nemecek and Kägi [29], respectively.

To calculate the fate of pesticides the general model of Hauschild [30], has been used to estimate the pesticide fractions arriving to the environmental compartments (soil, plant, surface- and groundwater). This fraction depends on both the physical and chemical properties and the degradation rate of the pesticide. These properties have been found in the following databases: Pesticide footprint 
[31], EU Pesticide Database [32], OSU Extension Pesticide Properties Database [33] and The Pesticide Manual [34]. Furthermore, a Leaf Area Index (LAI) of 6.04 has been taken into account [35] for the deposition of the pesticide on crops plants and field soil. The fraction that reaches the surrounding environment (drift off the field) has been calculated taking into account both the surface water and the surface area for both countries. A surface area of 2,320,000 ha-1 in the Valencia province and of $1,510,000 \mathrm{ha}^{-1}$ in the Calabria Region, and a water surface of $23,216 \mathrm{ha}^{-1}$ and of $2980 \mathrm{ha}^{-1}$ respectively, has been considered.

\subsubsection{Life Cycle Impact Assessment (LCIA)}

The purpose of the LCIA phase is to translate the environmental burdens quantified in the LCI into the related potential environmental impacts (or category indicators) [19]. To this aim Gabi 6.0 software [36] was used. The impacts assessment has been calculated by using a midpoint approach including the classification and characterisation steps. Ten impact categories have been considered: Global Warming Potential (GWP 100 year, measured as $\mathrm{kg} \mathrm{CO}_{2}$ eq), Acidification Potential (AP, measured as $\mathrm{kg} \mathrm{SO}_{2}$ eq), Eutrophication Potential (EP, measured as $\mathrm{kg} \mathrm{PO}_{4}{ }^{3-} \mathrm{eq}$ ), Abiotic Depletion (ADP elements, measured as $\mathrm{kg} \mathrm{Sb}$ eq), Abiotic Depletion (ADP fossil, measured in MJ), Ozone Layer Depletion Potential (ODP, measured as kg CFC-11 eq) and Photochemical Ozone Creation Potential (POCP, measured as kg Ethene eq) according to CML2001 method [34]. In addition, Ecotoxicity, Human toxicity carcinogenic and Human toxicity noncarcinogenic expressed in CTUe (comparative toxic units) and CTUh have been calculated according to USEtox method [37].

\section{Results interpretation}

The environmental performance of the conventional and organic clementine farming systems for the two countries summarized in table 1, as mean values (M) and standard deviation (SD) for each impact category. No greatest differences have been found between CFS and OFS in both countries and the impacts show a high variability depending on the farm.

As can be observed, the Spanish farms show higher variability, particularly the organic farms. This is due to the heterogeneity of the agricultural practices, in fact, different levels and kind of chemical and organic fertilizers, pesticides and machinery are used. In the case of Italian farms, both organic and conventional show more homogeneous practices and consequently the impact results present lower variability.

Figs 2 and 3 show the impacts generated by each production process stage in the Spanish and Italian CFS. The most impacting stage in almost all categories is the fertilizer production (GWP100: $\mathrm{CFS}_{\mathrm{Sp}} 89 \%-\mathrm{CFS}_{\mathrm{It}} 92 \%$; AP: CFS $\mathrm{Sp} 80 \%-$ $\mathrm{CFS}_{\text {It }}$ 91\%; ADPelements: CFS $\mathrm{Sp} 81 \%-\mathrm{CFS}_{\text {It }} 48 \%$; ADPfossil: $\mathrm{CFS}_{\mathrm{Sp}} 93 \%-$ $\mathrm{CFS}_{\text {It }}$ 96\%; ODP: $\mathrm{CFS}_{\text {Sp }}$ 93\% - CFS It $98 \%$; POCP: $\mathrm{CFS}_{\mathrm{Sp}} 90 \%-\mathrm{CFS}_{\text {It }}$ 93\%; Human Toxicity cancer: $\mathrm{CFS}_{\mathrm{Sp}} 97 \%$ - $\mathrm{CFS}_{\text {It }} 100 \%$; Human Toxicity non-cancer: $\mathrm{CFS}_{\mathrm{Sp}} 83 \%-\mathrm{CFS}_{\text {It }} 93 \%$ ) with the exception of the Ecotoxicity and EP categories in which the field operations have a great contribution (Ecotoxicity: $\mathrm{CFS}_{\mathrm{Sp}} 97 \%$ 
Table 1: Mean values and standard deviation for each impact category for clementine production. Conventional Farming System Spain (CFSSp) and Italy (CFSIt) - Organic Farming System Spain (OFSSp) and Italy (OFSIt).

\begin{tabular}{|c|c|c|c|c|c|c|c|c|}
\hline \multirow{3}{*}{$\begin{array}{c}\text { Impact } \\
\text { categories } \\
\text { [Units] }\end{array}$} & \multicolumn{4}{|c|}{ Conventional } & \multicolumn{4}{|c|}{ Organic } \\
\hline & \multicolumn{2}{|c|}{$C F S_{S p}$} & \multicolumn{2}{|c|}{$C F S_{I t}$} & \multicolumn{2}{|c|}{$O F S_{S p}$} & \multicolumn{2}{|c|}{$O F S_{I t}$} \\
\hline & $\mathrm{M}$ & SD & $\mathrm{M}$ & SD & $\mathrm{M}$ & SD & $\mathrm{M}$ & SD \\
\hline $\begin{array}{c}\text { GWP } 100 \text { yrs } \\
{\left[\mathrm{kg} \mathrm{CO}_{2} \text { eq }\right]}\end{array}$ & $1.37 \mathrm{E}+04$ & $1.06 \mathrm{E}+04$ & $2.87 \mathrm{E}+04$ & $2.83 \mathrm{E}+03$ & $3.57 \mathrm{E}+03$ & $5.48 \mathrm{E}+03$ & $2.80 \mathrm{E}+03$ & $1.71 \mathrm{E}+03$ \\
\hline $\begin{array}{c}\mathrm{AP} \\
{\left[\mathrm{kg} \mathrm{SO}_{2} \text { eq }\right]}\end{array}$ & $1.10 \mathrm{E}+02$ & $1.03 \mathrm{E}+02$ & $2.61 \mathrm{E}+02$ & $2.59 \mathrm{E}+01$ & $1.94 \mathrm{E}+02$ & $3.05 \mathrm{E}+02$ & $8.69 \mathrm{E}+01$ & $4.14 \mathrm{E}+01$ \\
\hline $\begin{array}{c}\mathrm{EP} \\
{\left[\mathrm{kg} \mathrm{PO}_{4}{ }^{3-} \mathrm{eq}\right]}\end{array}$ & $4.30 \mathrm{E}+01$ & $2.75 \mathrm{E}+01$ & $8.01 \mathrm{E}+01$ & $8.55 \mathrm{E}+00$ & $4.69 \mathrm{E}+01$ & $5.50 \mathrm{E}+01$ & $2.24 \mathrm{E}+01$ & $8.07 \mathrm{E}+00$ \\
\hline $\begin{array}{l}\text { ADP elements } \\
\text { [kg Sb eq] }\end{array}$ & $1.17 \mathrm{E}-02$ & 7.37E-03 & $9.01 \mathrm{E}-03$ & $6.12 \mathrm{E}-03$ & 4.62E-04 & $1.23 \mathrm{E}-03$ & $3.17 \mathrm{E}-04$ & $3.86 \mathrm{E}-04$ \\
\hline $\begin{array}{c}\text { ADP fossil } \\
{[\mathrm{MJ}]}\end{array}$ & $1.26 \mathrm{E}+05$ & $1.16 \mathrm{E}+05$ & $3.05 \mathrm{E}+05$ & $3.04 \mathrm{E}+04$ & $2.86 \mathrm{E}+04$ & $5.98 \mathrm{E}+04$ & $2.90 \mathrm{E}+04$ & $1.62 \mathrm{E}+04$ \\
\hline $\begin{array}{c}\text { ODP } \\
{[\mathrm{kg} \mathrm{CFC}-11 \mathrm{eq}]}\end{array}$ & 7.30E-04 & $5.86 \mathrm{E}-04$ & $1.56 \mathrm{E}-03$ & $1.62 \mathrm{E}-04$ & $1.17 \mathrm{E}-04$ & $3.17 \mathrm{E}-04$ & $4.96 \mathrm{E}-05$ & $7.20 \mathrm{E}-05$ \\
\hline $\begin{array}{c}\text { POCP } \\
{[\mathrm{kg} \text { Ethene eq] }}\end{array}$ & $5.08 \mathrm{E}+00$ & $5.02 \mathrm{E}+00$ & $1.32 \mathrm{E}+01$ & $1.30 \mathrm{E}+00$ & $1.42 \mathrm{E}+00$ & $2.57 \mathrm{E}+00$ & $1.88 \mathrm{E}+00$ & $9.98 \mathrm{E}-01$ \\
\hline $\begin{array}{c}\text { Ecotoxicity } \\
\text { [CTUe] }\end{array}$ & $9.41 \mathrm{E}+05$ & $5.40 \mathrm{E}+05$ & $3.39 \mathrm{E}+05$ & $1.45 \mathrm{E}+05$ & $9.18 \mathrm{E}+04$ & $3.17 \mathrm{E}+05$ & $2.54 \mathrm{E}+03$ & $3.29 \mathrm{E}+03$ \\
\hline $\begin{array}{c}\text { Human toxicity } \\
\text { cancer } \\
\text { [CTUh] }\end{array}$ & $4.36 \mathrm{E}-04$ & 4.57E-04 & $1.12 \mathrm{E}-03$ & $1.20 \mathrm{E}-04$ & $7.04 \mathrm{E}-05$ & $2.29 \mathrm{E}-04$ & $3.42 \mathrm{E}-05$ & 4.94E-05 \\
\hline $\begin{array}{l}\text { Human toxicity } \\
\text { non-cancer } \\
\text { [CTUh] }\end{array}$ & $2.15 \mathrm{E}-03$ & $1.77 \mathrm{E}-03$ & $4.63 \mathrm{E}-03$ & $5.07 \mathrm{E}-04$ & $4.50 \mathrm{E}-04$ & $9.64 \mathrm{E}-04$ & $5.06 \mathrm{E}-04$ & $2.71 \mathrm{E}-04$ \\
\hline
\end{tabular}

$\mathrm{CFS}_{\text {It }} 78 \%$ and EP: $\mathrm{CFS}_{\mathrm{Sp}} 49 \%-\mathrm{CFS}_{\text {It }} 40 \%$ ). Pesticides manufacturing presents an important contribution to ADPelements for the two countries $\left(\mathrm{CFS}_{\mathrm{Sp}} 18 \%-\right.$ $\mathrm{CFS}_{\text {It }} 52 \%$ ).

The impacts generated in the OFS are presented in figs 4 and 5. The results show that the main difference between Italian and Spanish organic farms arises in the Ecotoxicity category. In Spain, the $95 \%$ of the impact is produced in the field operation stage, while in Italy the $87 \%$ is caused by the fertilizers. The impacts generated by the machinery present the following percentages: GWP100: OFS $18 \%-$ OFS $_{\text {It }} 51 \%$; AP: OFS 3 Sp $3 \%-$ OFS $_{\text {It }} 14 \%$; EP: OFS $3 \%-$ OFS $_{\text {It }} 13 \%$; ADPelements: OFS $6 \%$ - OFS 1 It $17 \%$; ADPfossil: OFS $_{\mathrm{Sp}} 32 \%-$ OFS $_{\text {It }} 69 \%$;

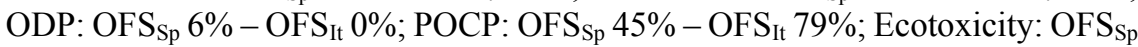
$0 \%-\mathrm{OFS}_{\text {It }} 13 \%$; Human Toxicity cancer: OFS $1 \%-\mathrm{OFS}_{\mathrm{It}} 3 \%$; Human Toxicity 


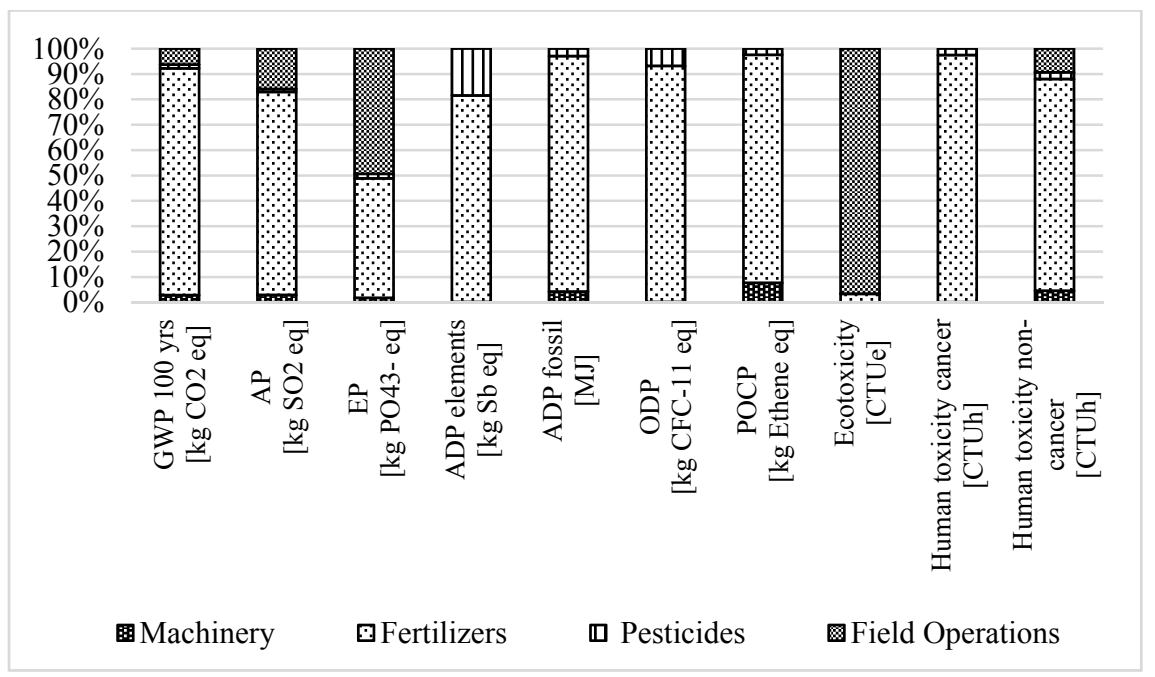

Figure 2: Impacts per production stage in conventional clementine production in Spain.

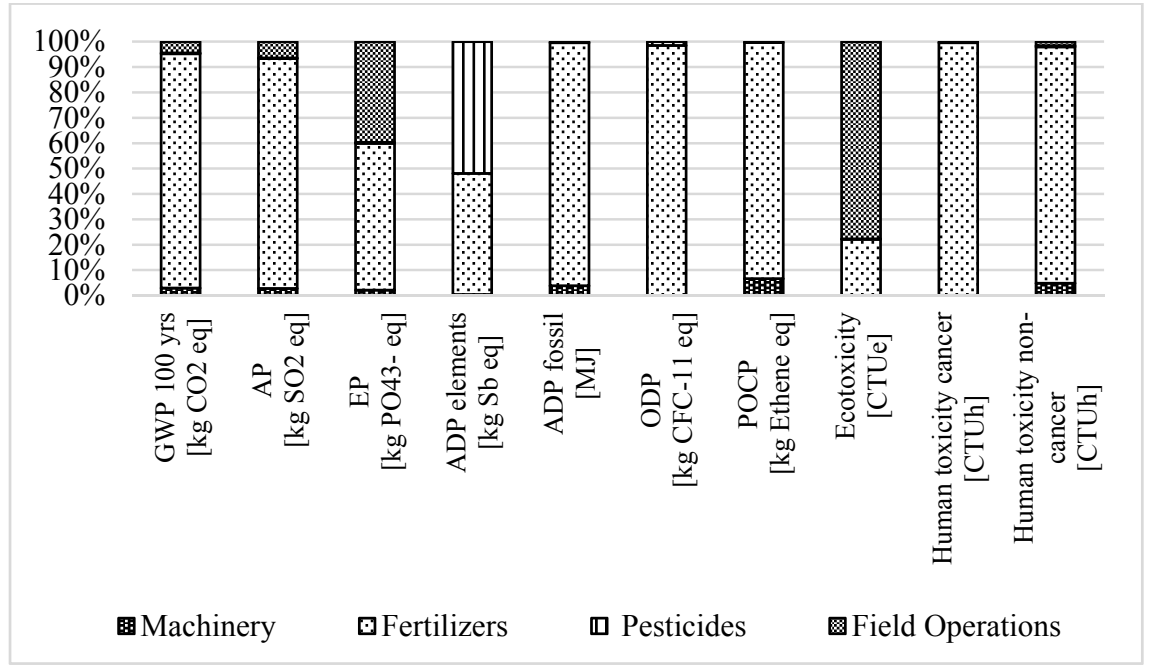

Figure 3: Impacts per production stage in conventional clementine production in Italy.

non-cancer: $\mathrm{OFS}_{\mathrm{Sp}} 35 \%-\mathrm{OFS}_{\text {It }} 75 \%$. As in the CFS, the fertilizers manufacturing present higher impacts in almost all categories, in particular, in the ODP category for both countries the values are significantly higher $\left(\mathrm{OFS}_{\mathrm{Sp}} 80 \%-\mathrm{OFS}_{\mathrm{It}} 97 \%\right)$. Finally, the pesticide stage contribute to the production of impacts in the AP (36\%) and ODP (15\%) categories, only in Spain. In general, the impacts generated by OFS were lower than those for CFS. 


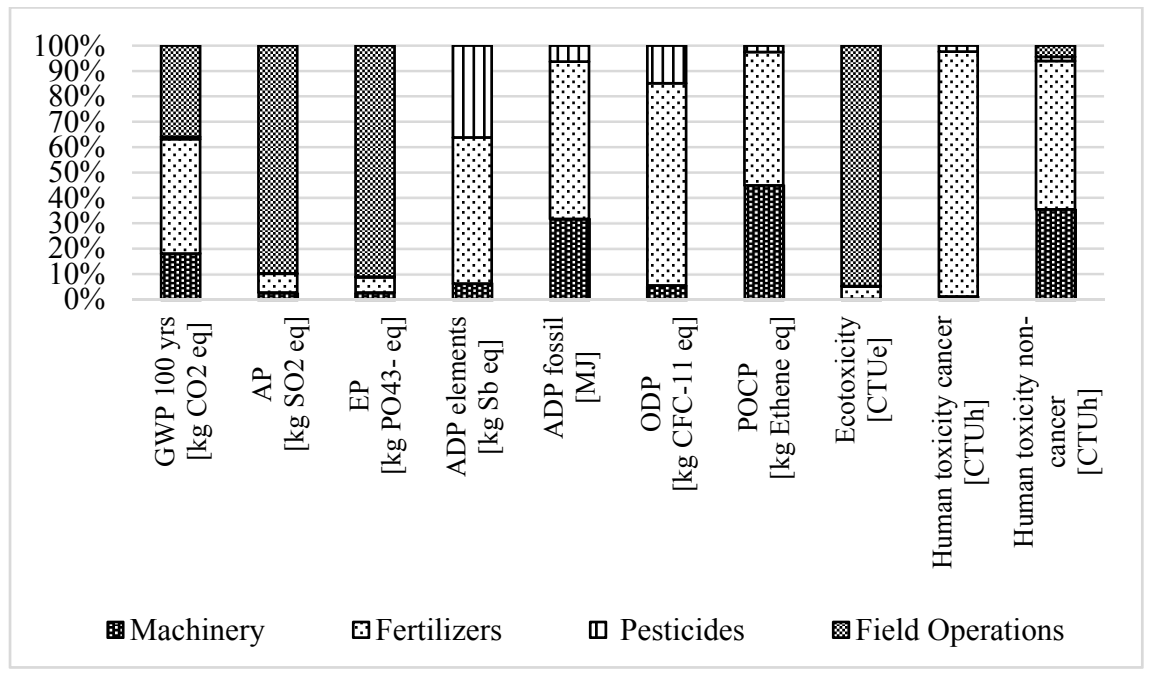

Figure 4: Impacts per production stage in organic clementine production in Spain.

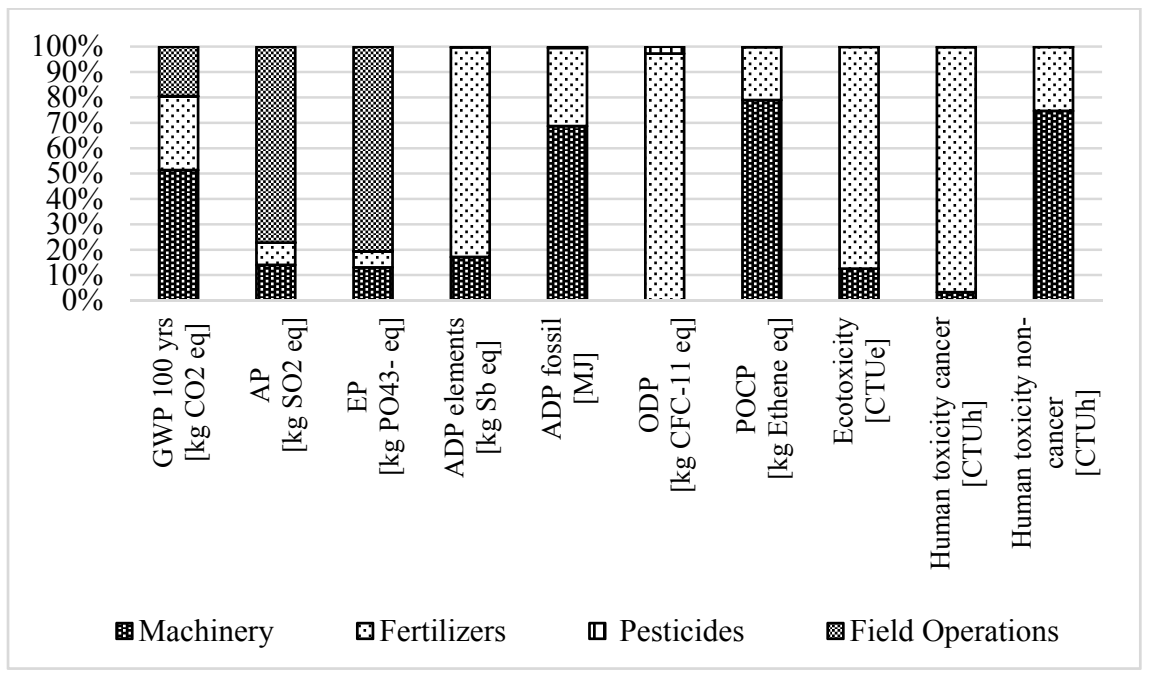

Figure 5: Impacts per production stage in organic clementine production in Italy.

\section{Discussion}

The environmental performance obtained by comparing organic and conventional cropping systems in Spain and Italy shows small differences between both production areas for the impact categories selected. This phenomenon it is likely 
due to similar pedoclimatic conditions that conducted to comparable agricultural techniques and similar biocenotic processes. However, although the mean results show comparable performances, the Spanish farms show a higher variability in the impact results, due to a higher adaptation of cultivation techniques to the individual farm, as a consequence of more advanced farm management techniques.

De Luca et al. [10] performed a similar study in Calabria region but findings are not comparable because they used an end-point LCIA method (Ecoindicator 99) which expresses the environmental impacts from a damage oriented perspective. Pergola et al. [9] analyzed the production of lemons and oranges in Sicily region taking into account the whole life cycle of the orchard (50 years). These authors used the same impact assessment method as the one in this study and chose, however, five impact categories (AD, GWP100yrs, PO, AA, EU). When partitioning the total results for one production year, impact values are lower, this is due, among other reasons, to the influence of the planting and growing phase, in which the lower quantity of inputs applied reduces the mean value of the impact per year.

Dwivedi et al. [38] analyzed the production of orange juice in Florida, considering a farm cradle to industry gate system boundary. Results are related to $1893 \mathrm{~L}$ of Not-From-Concentrate orange juice. Considering an average production of $45 \mathrm{t}$ oranges/hectare and comparing results in term of GWP, the average value of $303 \mathrm{~g} \mathrm{CO}_{2} / \mathrm{kg}$ clementine for the Spanish conventional farming system is similar to Dwivedi's result (312 g CO $\mathrm{CO}_{2} / \mathrm{kg}$ orange). Contrariwise, the Calabrian conventional farming system generates around $637 \mathrm{~g} \mathrm{CO}_{2} / \mathrm{kg}$ clementine. This value is mostly due to the higher quantity of fertilizer spread, which represents the most impacting operation for CFSIt. The reduction of the fertilizer dose could improve the environmental performances of these farms.

\section{Conclusion}

In this study the importance of the variability of management practices has been analyzed. The results show how, independently of the farming system, a proper management enables to generate both relatively low environmental impacts and costs contributing to the aim of sustainability.

\section{References}

[1] FAOSTAT (2012), http://faostat3.fao.org/home/E.

[2] Ministerio de Agricultura, Alimentación y Medio Ambiente (2011), http:/www.magrama.gob.es/es/estadistica/temas/estadisticas-agrarias/ agricultura/default.aspx.

[3] ISTAT, $6^{\text {th }}$ Italian agriculture census. http://www.istat.it/it/censimentoagricoltura/agricoltura-2010.

[4] Agri-istat (2010), http://agri.istat.it/.

[5] Guinée, J.B., Gorrée, M., Heijungs, R., Huppes, G., Kleijn, R., de Koning, A., van de Oers, L., Sleeswijk, A.W., Suh, S. \& Udo de Haes, H.A., 
Handbook on Life Cycle Assessment. Operational Guide to the ISO standards, Kluwer Academic Publishers: The Netherlands, 2002.

[6] Sanjuán, N., Ubeda, L., Clemente, G., Girona, F., \& Mulet, A., LCA of integrated orange production in the Comunidad Valenciana (Spain). International Journal of Agricultural Resources, Governance and Ecology, 4(2), pp. 163-177, 2005.

[7] Beccali, M., Cellura, M., Iudicello, M. \& Mistretta M., Resource Consumption and Environmental Impacts of the Agrofood Sector: Life Cycle Assessment of Italian Citrus-Based Product. Environmental Management, 43, pp. 707-724, 2009.

[8] Knudsen, M. T., de Almeida, G. F., Langer, V., de Abreu, L. S., \& Halberg, N., Environmental assessment of organic juice imported to Denmark: a case study on oranges (Citrus sinensis) from Brazil. Organic Agriculture, 1(3), pp. 167-185, 2011.

[9] Pergola, M., D’amico, M., Celano, G., Palese, A.M., Scuderi, A., Di Vita, G., Pappalardo, G. \& Inglese, P., Sustainability evaluation of Sicily's lemon and orange production: An energy, economic and environmental analysis. Journal of Environmental Management, 128, pp. 674-682, 2013.

[10] De Luca, A.I., Falcone, G., Stillitano, T., Strano, A. \& Gulisano, G., Sustainability Assessment of Quality-Oriented Citrus Growing Systems in Mediterranean Area. QUALITY access to success, 15(141), pp. 103-108, 2014.

[11] Mouron, P., Nemecek, T., Scholz, R.W. \& Weber, O., Management influence on environmental impacts in an apple production system on Swiss fruit farms: Combining life cycle assessment with statistical risk assessment. Agriculture, Ecosystems and Environment, 114, pp. 311-322, 2006.

[12] Da Silva, V.P., Van der Werf, H.M.G., Spies, A. \& Soares, S.R., Variability in environmental impacts of Brazilian soybean according to crop production and transport scenarios. Journal of Environmental Management, 91(9), pp. 1831-1839, 2010.

[13] Basset-Mens, C., Kelliher, F.M., Ledgard, S. \& Cox, N., Uncertainty of global warming potential for milk production on a New Zealand farm and implications for decision making. Int. J. Life Cycle Assess., 14, pp. 630$638,2009$.

[14] ISO 14040:2006, Environmental management - Life Cycle Assessment Principles and framework, International Organization for Standardization, ISO: Geneva, 2006.

[15] ISO 14044:2006 Environmental management - Life Cycle Assessment Requirements and guidelines, International Organization for Standardization, ISO: Geneva, 2006.

[16] Milà i Canals, L. \& Clemente Polo, G., LCA of fruit production (Chapter 4). Environmentally-friendly food processing eds. B. Mattsson \& U. Sonesson, Woodhead Publishing Ltd: Cambridge (UK), pp. 29-53, 2003.

[17] Bentrup, F., Life cycle assessment of crop production (Chapter 4). Green Technologies in Food Production and Processing, eds. J. I. Boye \& Y. 
Arcand, Springer: New York Dordrecht Heidelberg London, pp. 61-82, 2012.

[18] Frischknecht, R., Althaus, H.J., Bauer, C., Doka, G., Heck, T., Jungbluth, N., Kellenberger, D. \& Nemecek, T., The Environmental Relevance of Capital Goods in Life Cycle Assessments of Products and Services. Int. J. Life Cycle Assess., 12(1), pp. 7-17, 2007.

[19] Azapagic, A., Life Cycle Assessment as an Environmental Sustainability Tool (Chapter 6). Renewables-Based Technology eds. J. Dewulf \& H. Van Langenhove, John Wiley \& Sons Ltd: The Atrium, Southern Gate, Chichester, West Sussex PO 19 8SQ (UK), pp. 87-110, 2006.

[20] Ecoinvent 2.1, Swiss Centre for Life Cycle Inventories, Swiss. http://www.ecoinvent.org/database/.

[21] Audsley, E., Alber, S., Clift, R., Cowell, S., Crettaz, P., Gaillard, G., Hausheer, J., Jolliett, O., Kleijn, R., Mortensen, B., Pearce, D., Roger, E., Teulon, H., Weidema, B., van Zeijts, H., Harmonisation of environmental life cycle assessment for agriculture. Final Report, Concerted Action AIR3CT94-2028 European Commission, DG VI Agriculture, p. 139, 1997.

[22] Patyk, A. \& Reinhardt, G., Düngemittel - Energie - und Stoffstromsbilanzen. Friedr. Vieweg \& Sohn Publishers: Braunschweig/Wiesbaden, Germany, 1997.

[23] Oficina Catalana de Canvi Climàtic, Guía práctica para el cálculo de emisiones de gases de efecto invernadero (GEI), Generalitat de Catalunya: Cataluña, 2013.

[24] 2006 IPCC Guidelines for National Greenhouse Gas Inventories. Volume 4 Agriculture, forestry and other land uses; The Intergovernmental Panel on Climate Change (IPCC), Online.

[25] MAGRAMA; Ministerio de Agricultura, Alimentación y Medio Ambiente, http://www.magrama.gob.es/app/consultafertilizante/consultafertilizante.as px\#

[26] Organazoto Fertilizzanti SpA, http://www.organazoto.it/en/products/8? type $=$ F\&id $=1294 \&$ linea $=$ organici, http://www.ipcc-nggip.iges.or.jp/public $/ 2006 \mathrm{gl} / \mathrm{vol} 4 . \mathrm{html}$

[27] Bentrup, F., Küsters, J., Lammel, J., Kuhlmann, H., Methods to estimate onfield nitrogen emissions from crop production as an input to LCA studies in the agricultural sector. Int. J. Life Cycle Assess., 5(6), pp. 349-357, 2000.

[28] MARM, Balance del nitrógeno en la agricultura española (Año 2008). Resumen de resultados y criterios utilizados, Comunidad Valenciana. Dirección general de recursos agrícolas y ganaderos, Ministerio de Medio Ambiente, Medio Rural y Marino (Ministerio de Agricultura, Alimentación y Medio Ambiente): Madrid, 2010.

[29] Nemecek, T. \& Kägi, T., Life cycle Inventories of Swiss and European Agricultural Production Systems, Final report ecoinvent V2.0 No. 15a. Agroscope Reckenholz-Taenikon Research Station ART, Swiss Centre for Life Cycle Inventories: Zurich and Dübendorf, CH, 2007.

[30] Hauschild, M., Estimating pesticide emissions for LCA of agricultural products. Agricultural data for Life Cycle Assessments, eds. B.P. Weidema 
\& M.J.G. Meeusen, The Hague, Agricultural Economics Research Institute (LEI): Netherlands, pp. 64-79, 1999.

[31] University of Hertfordshire, PPDB Pesticide Properties Database, United Kingdom. http://sitem.herts.ac.uk/aeru/footprint/index2.htm.

[32] EU Pesticides Database, http://ec.europa.eu/sanco_pesticides/ public/index.cfm? event=homepage \&language $=\mathrm{EN}$.

[33] National Pesticide Information Center (NPIC). OSU Extension Pesticide Properties Database, Oregon State University, Oregon, http://npic.orst.edu/ingred/ppdmove.htm.

[34] McBean, C., A world compendium. The pesticide manual. Sixteenth Edition, BCPC (British Crop Production Council): United Kingdom (UK), p. 1440, 2012.

[35] Martins, N. \& Sanjuán, N., Impact assessment of pesticides toxicity and water use in integrated orange production in the Comunidad Valenciana, Valencia, Spain, 2006.

[36] $\mathrm{GaBi}$ software; PE International. http://www.gabi-software.com/ international/software/gabi-software/.

[37] UNEP/SETAC Life Cycle Initiative, USEtox model and factors, http://www.usetox.org/.

[38] Dwivedi, P., Spreen, T. \& Goodrich-Schneider, R., Global warming impact of Florida's Not-From-Concentrate (NFC) orange juice. Agricultural Systems, 108, pp. 104-111, 2012. 